\title{
FLOOD MODELING OF THE VUKA RIVER SECTION UPSTREAM OF ITS CONFLUENCE WITH THE DANUBE RIVER
}

\author{
Dario Marić \\ Josip Juraj Strossmayer University of Osijek, Faculty of Civil Engineering Osijek, mag.ing.aedif. \\ Ivan Hrskanović \\ Josip Juraj Strossmayer University of Osijek, Faculty of Civil Engineering Osijek, mag.ing.aedif. \\ Tamara Dadić \\ Josip Juraj Strossmayer University of Osijek, Faculty of Civil Engineering Osijek, Ph.D. \\ Corresponding author: tamaradadic@gfos.hr \\ Lidija Tadić \\ Josip Juraj Strossmayer University of Osijek, Faculty of Civil Engineering Osijek, Full Professor
}

Professional paper / Stručni rad

\begin{abstract}
In this paper, a section of the Vuka River from its confluence with the Danube River in Vukovar to $3+$ $630 \mathrm{rkm}$ was modeled. The possibility and size of floods in the surrounding area were analyzed for different return periods $(2,5,10,50$, and $100 \mathrm{yrs})$. Although the high-water levels of the Danube River are lower than the terrain elevation of Vukovar, they cause backwater in the Vuka River and in its tributary, the Bobotski canal. In that indirect way, the surrounding area is endangered and the efficiency of drainage systems is reduced. The existing riverbed of the analyzed Vuka River section was digitalized based on a digital terrain model using the geographic information system (GIS) software ArcGIS and the HEC-GeoRAS toolbar. A mathematical model of the steady-state flow of the Vuka river section using the digitized riverbed was executed in the HEC-RAS software using different return periods. The obtained velocities and water levels were analyzed using HEC-RAS, and the sizes of the flooded areas were calculated and observed in ArcGIS.
\end{abstract}

Key words: Vuka River, flooded area, return period, mathematical model, ArcGIS, HEC-RAS

\section{MODELIRANJE PLAVLJENJA DIONICE RIJEKE VUKE UZVODNO OD UŠĆA U DUNAV}

Sažetak: U radu je modelirana dionica rijeke Vuke od samog ušća u Dunav u Vukovaru do 3+630 rkm, pri čemu je analizirana mogućnost pojave poplava, uzimajući u obzir povratna razdoblja od 2, 5, 10, 50 i 100 godina. lako maksimalni vodostaji rijeke Dunav ne premašuju kote, uglavnom, nizinskog terena područja grada Vukovara, uzrokuju uspore u rijeci Vuki i njezinom pritoku Bobotskom kanalu. Na taj, indirektan način, ugrožavaju okolno područje i smanjuju učinkovitost zaobalnih sustava površinske odvodnje. Na digitalnom modelu terena korita rijeke Vuke i inundacijskog područja, u GIS računalnom programu ArcGIS pomoću alatne trake HEC-GeoRAS, digitalizirano je postojeće korito rijeke Vuke. Na tako definiranoj dionici napravljen je matematički model stacionarnog strujanja u računalnom programu HEC-RAS prema različitim povratnim razdobljima. Dobivene brzine strujanja i vodostaji analizirani su u samom programu HEC-RAS, dok se veličina poplavnih područja analizirala u ArcGIS-u.

Ključne riječi: rijeka Vuka, poplavna područja, povratna razdoblja, matematički model, ArcGIS, HEC-RAS 


\section{INTRODUCTION}

The Vuka River emerges from the north-eastern part of Krdnija near the village of Paučje from the foothills of mount Borovik. Its $112 \mathrm{~km}$ length extends throughout the lowland terrain in the north-western part of Slavonia and Srijem. The Vuka River has two parts: an upper section with greater longitudinal decline, and a lower section with very small decline. As a result, numeorus meanders have formed in the lower part. The Vuka River flows into the Danube River at Vukovar. The size of the catchment area of the Vuka River is $1759 \mathrm{~km}^{2}$. It is covered with a dense network of surface drainage canals and a series of mountain streams from the slopes of Krndija [1, 2]. The altitudes of the lowest part of the catchment area, formerly called the Palača swamp, do not exceed an elevation of 80 ma.s.l. The size of this part is $200 \mathrm{~km}^{2}$, and throughout history, it has often flooded. It used to be a lake, but it was drained by a surface drainage system whose construction began in 1830. Even today, many depressions can be found in this area. The surface drainage is performed mechanically with pump stations [2, 3].

Floods in this area are dependent on the hydrological regime of the Vuka River and on the high-water levels of the Danube and Drava Rivers. Although the high-water levels of the Danube River are lower than the terrain elevation of Vukovar, they cause backwater in the Vuka River and in its tributary, the Bobotski canal. In consequence, the surrounding area is endangered and the efficiency of drainage systems is reduced. Until regulation works in the $20^{\text {th }}$ century, the confluence of the Vuka River was upstream of flow in the Danube River, which also caused backwater. Today, the confluence is regulated and is perpendicular to the flow. Part of the old confluence was transformed into a river port [1, 2].

This area has experienced numerous floods, one of the first of which to be recorded was in 1870 . The magnitude of the flood was described very vividly, with apparently only the tops of the trees visible above the water. In 1965, one of the biggest floods affected this area. Even today, because of the high water levels of the Danube River and the backwater in the Vuka River, Vukovar and its surrounding area are often subjected to floods, such as those in 2006 and 2010 [4].

In order to obtain a detailed insight into the frequency and magnitude of floods that occur in this area, a mathematical model of the downstream part of the Vuka River and its confluence was constructed.

\section{ANALYSIS OF INPUT DATA}

The analyzed section of the Vuka River is from its confluence with the Danube River to $3+630 \mathrm{rkm}$. The downstream section passes through Vukovar (Figure 1). The right bank was formed by filling materials, whereas the left one is in naturally high terrain. The upstream part of analyzed section passes through a wide valley of the Vuka River where eutrophication takes place. There are four pedestrian bridges, two road bridges, and one railway bridge on this section of the Vuka River. None of these bridges has supports within the riverbed, and thus, there is no resistance to the water flow.

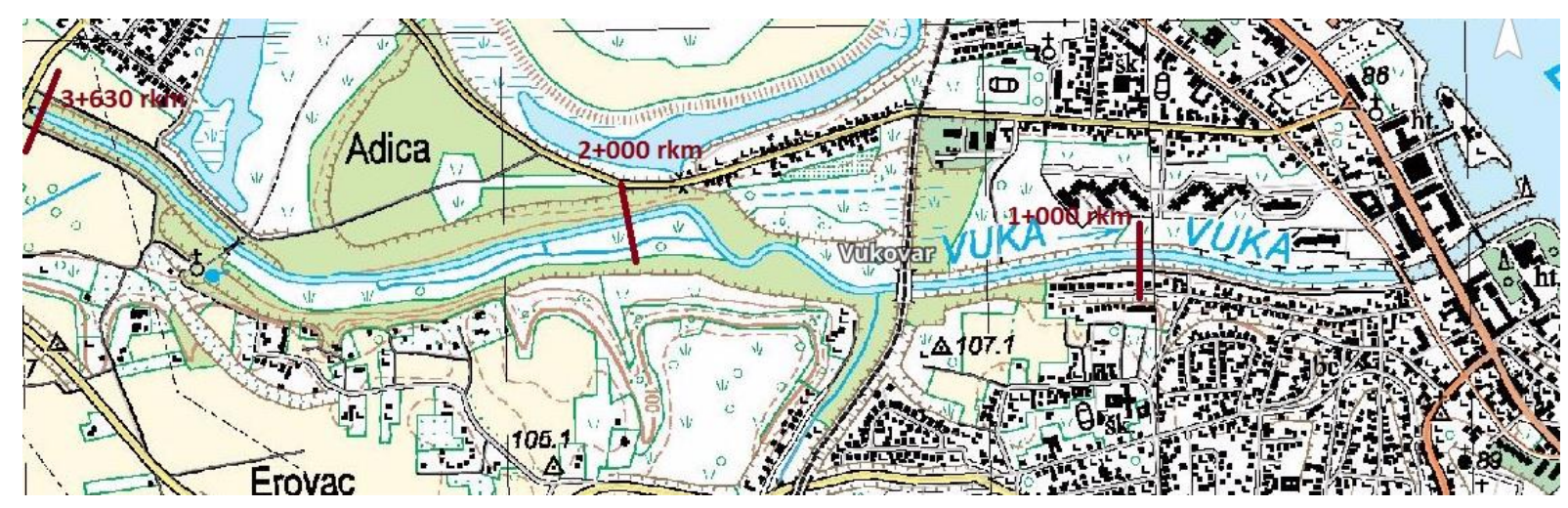

Figure 1 - Analyzed section of the Vuka River [5]

Marić, D, Hrskanović, I, Dadić, T, Tadić, L 
A digital model of the Vuka River in the "dem" format that contains terrain altitude was used. The river axis, banks, and cross sections for every $50 \mathrm{~m}$ were obtained by model processing in ArcGis using the Hec-GeoRas toolbar [6] (Figure 2).

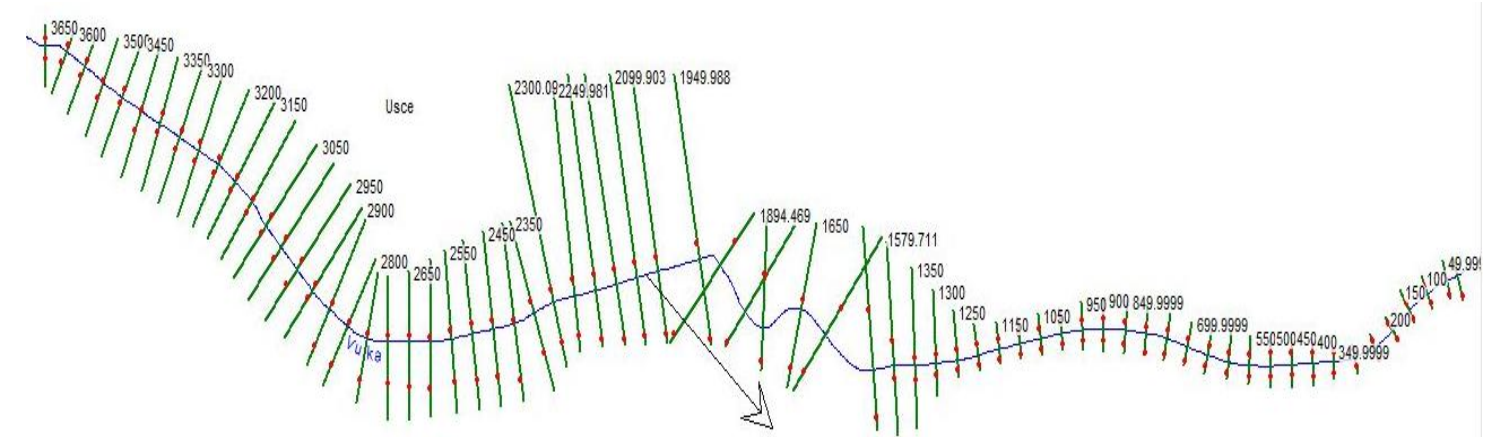

Figure 2 - Geometry of the Vuka River

In order to define Manning roughness coefficients for the riverbed and inundation areas, the digital database Corine Land Cover (CLC) was used. This contains land covers for the entire country, is in accordance with the database for the whole of Europe, and contains data from 1980 to 2012. There are three levels of CLC classification. The first level includes five general land-cover categories, which are divided in 15 subcategories that form the second level; the third level has a total of 44 classes of land cover [7, 8]. By overlapping the analyzed area with the CLC database (Figure 3), a matching Manning roughness was defined for each land-cover type and its code.

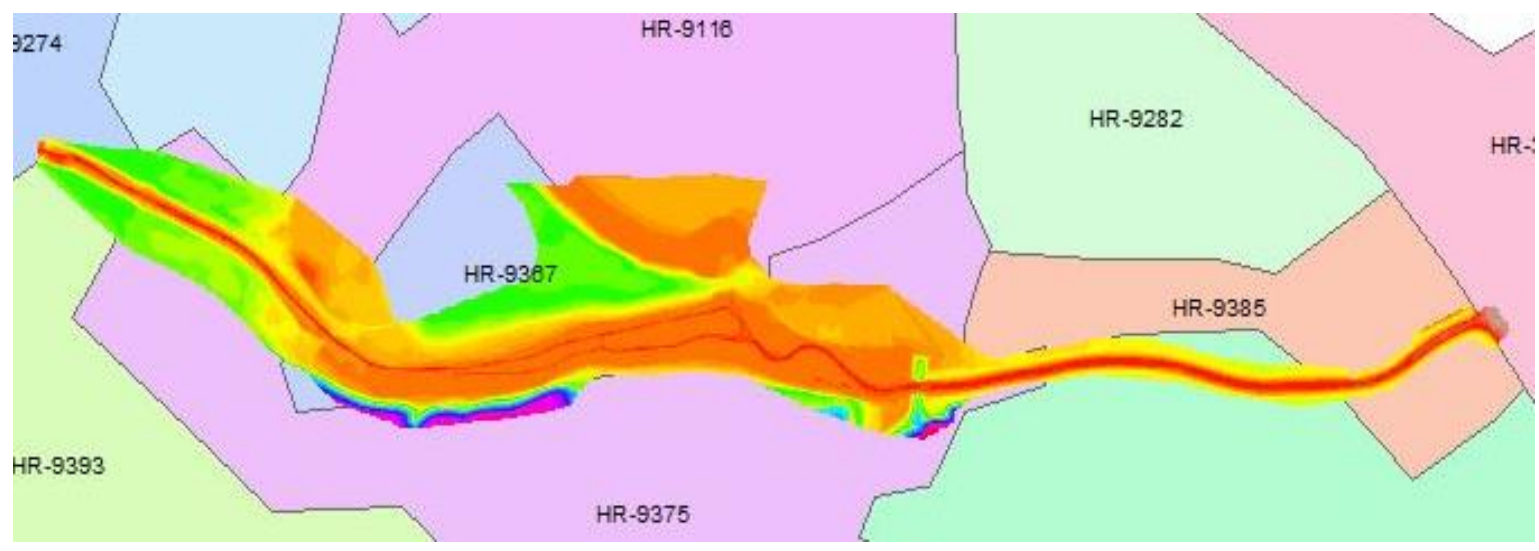

Figure 3 - Overlapping of digital terrain model and CLC database

All components of the Vuka River section were imported into the HEC-RAS computer software [9], with which the hydraulic analysis of the steady-state flow was performed. Before doing so, it was necessary to define the relevant discharges and water levels. These were obtained using the Log-Pearson Type III distribution, as recommended for flood frequency analysis by the U.S. Water Resources Council [10-12]. The main advantage of this method is its successful application to relatively short time series in order to obtain floods for much longer return periods. The calculation is based on the following equation [13, 14]:

$\log x_{P R}=\overline{\log x}+K \cdot \sigma \log x$

where the variables are defined as follows: 
$X_{P R}-$ variable value relevant for different return periods,

$x$ - random variable (discharge, water level),

$\overline{\log x}$ - mean value of logarithms of random variables,

$\mathrm{K}$ - frequency coefficient (function of skewness coefficient $\mathrm{Cs}$ and return period),

$\sigma$ - standard deviation.

The discharges defined using the Log-Pearson Type III distribution for different return periods are listed in Table 1. For the calculation, the discharges measured on the Vuka River between 2005 and 2011 (34 records) at gauging station Tordinci were used. This station is situated upstream from analyzed section, but it is the closest one. For comprehensive hydraulic analysis longer time series should be used, but there are no older records for this station. Also, calibration is needed for more detailed analysis, so this model provides insight into flood occurrence on analyzed area. Discharges were calculated for return periods of 2, 5, 10, 25, 50, and $100 \mathrm{yrs}$.

Table 1 Discharges $Q$ for different return periods using Log-Pearson III distribution

\begin{tabular}{ccccccc} 
Probability & Return period & $\mathbf{K}_{\mathbf{1}}(\mathbf{C}=\mathbf{0 . 2})$ & $\mathbf{K}_{\mathbf{2}}(\mathbf{C}=\mathbf{0 . 3})$ & $\mathbf{K}$ & $\log \mathbf{Q}$ & $\mathbf{Q}\left[\mathrm{m}^{3} / \mathbf{s}\right]$ \\
\hline 50 & 2 & -0.033 & -0.05 & -0.044 & 0.048 & 1.118 \\
20 & 5 & 0.83 & 0.824 & 0.825 & 0.694 & 4.944 \\
10 & 10 & 1.301 & 1.309 & 1.306 & 1.050 & 11.230 \\
4 & 25 & 1.818 & 1.849 & 1.839 & 1.445 & 27.881 \\
2 & 50 & 2.159 & 2.211 & 2.194 & 1.708 & 51.136 \\
1 & 100 & 2.472 & 2.544 & 2.520 & 1.950 & 89.303
\end{tabular}

In the same manner, the water levels for the same return periods were calculated (Table 2). Analyzed section of Vuka River is under direct influence of Danube River backwater so for this calculation, the water levels observed on the Danube River in Vukovar between 2005 and 2010 were used. Because of this direct influence and dominant Danube River, coincidence between two rivers was not analyzed.

Table 2 - Water levels $\mathrm{H}$ for different return periods using Log-Pearson III distribution

\begin{tabular}{ccccccc} 
Probability & Return period & $\mathbf{K}_{\mathbf{1}}(\mathbf{C}=-\mathbf{0 . 2})$ & $\mathbf{K}_{\mathbf{2}}(\mathbf{C}=-\mathbf{0 . 3})$ & $\mathbf{K}$ & Log $\mathbf{H}$ & $\mathbf{H}$ [ma.s.I.] \\
\hline 50 & 2 & 0.033 & 0.05 & 0.053 & 1.912 & 81.580 \\
20 & 5 & 0.85 & 0.853 & 0.853 & 1.917 & 82.546 \\
10 & 10 & 1.258 & 1.245 & 1.242 & 1.919 & 83.073 \\
4 & 25 & 1.680 & 1.643 & 1.635 & 1.922 & 83.651 \\
2 & 50 & 1.945 & 1.890 & 1.879 & 1.924 & 84.032 \\
1 & 100 & 2.178 & 2.104 & 2.089 & 1.926 & 84.377
\end{tabular}

\section{RESULTS}

The results of the hydraulic analysis (e.g., water levels, velocities, and Froude number) can be observed directly in the HEC-RAS software on the longitudinal profile and in cross section. Tables and graphs can be used as well. Analysis of the flooded areas was performed using ArcGis and the HEC-GeoRAS toolbar. The hydraulic model was imported from HEC-RAS into the geographic information system (GIS) software and was overlapped with a map of the analyzed area. All results are shown according to different return periods.

Figure 4 presents a longitudinal profile of the analyzed section of the Vuka River, and Figure 5 shows a velocity distribution along the longitudinal profile. The maximum velocities correspond to the highest return period 
and occur $500 \mathrm{~m}$ upstream from the confluence. The minimum velocities occur along the section of natural floodplain (1+500 to $2+500 \mathrm{rkm})$.

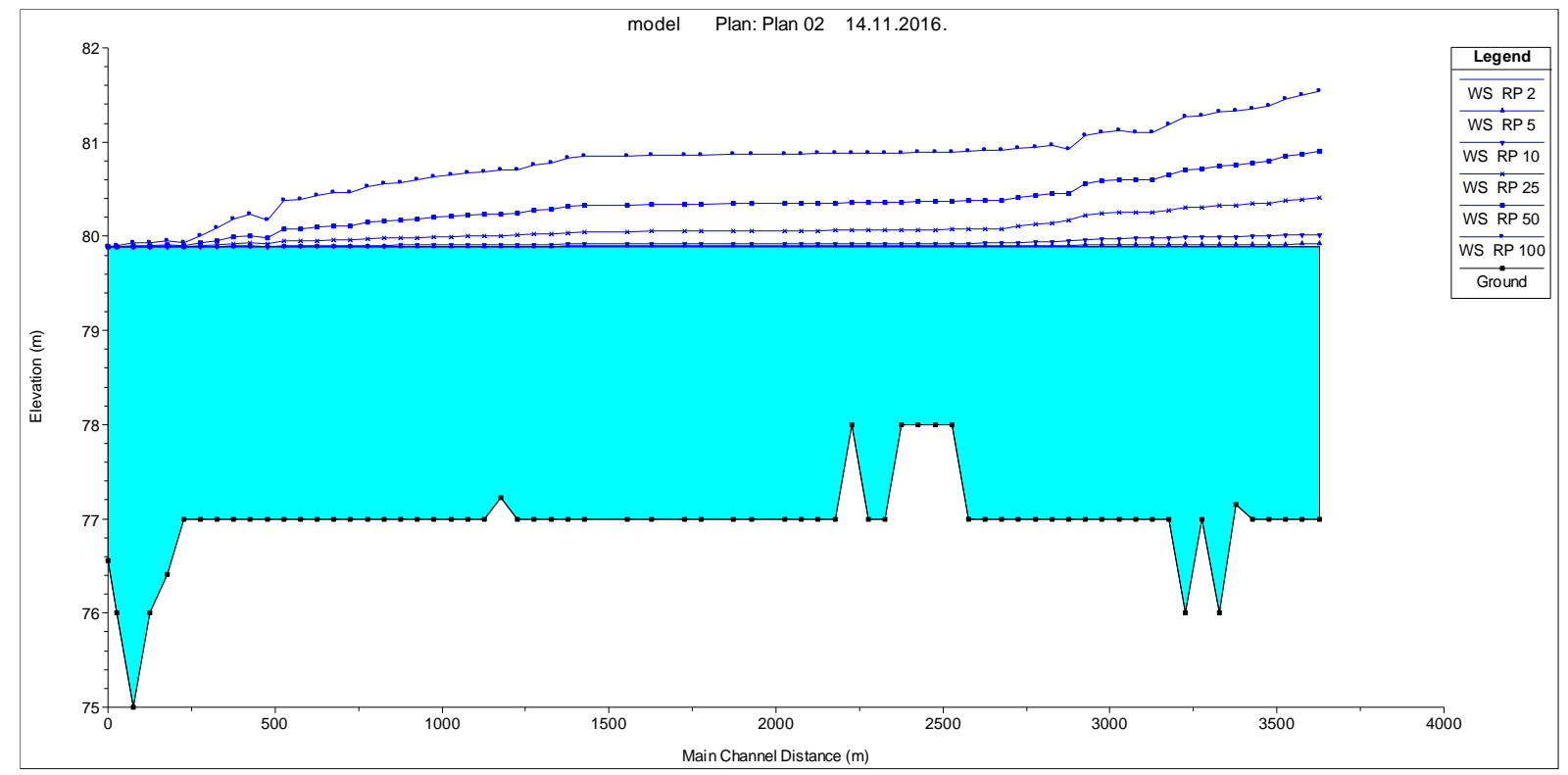

Figure 4 Longitudinal section of the Vuka River and water levels corresponding to different return periods

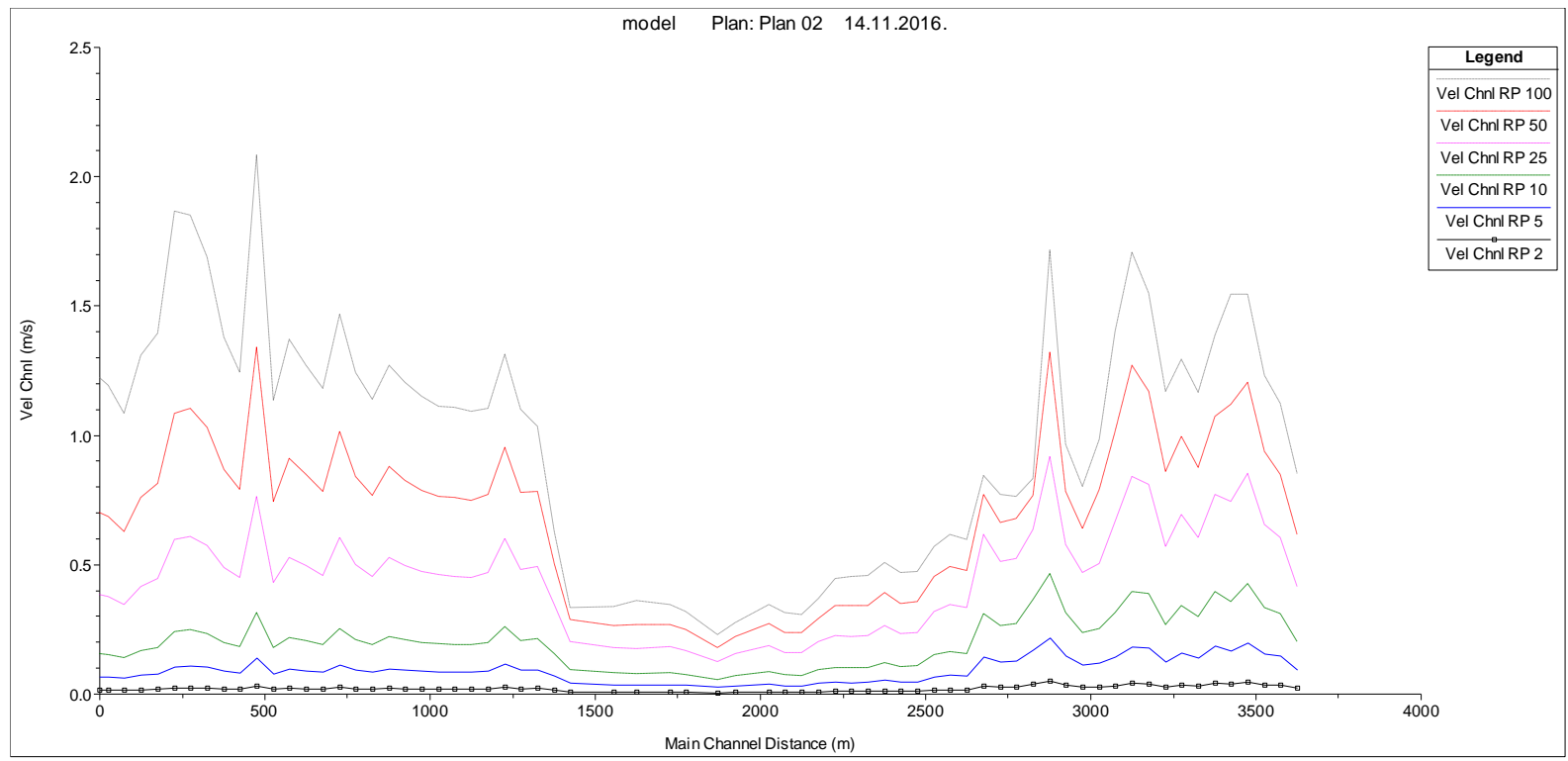

Figure 5 Distribution of velocities in the longitudinal profile of the Vuka River for different return periods

The results obtained from the hydraulic analysis for the cross section that is closest to the confluence with the Danube River are considered. The water levels for different return periods are shown in Figure 6 . The velocities, flow areas, top width, and other parameters obtained from the hydraulic simulation are listed in Table 3. 


\section{Flood modeling of the Vuka River section upsteam of is confuence with the Danube River}

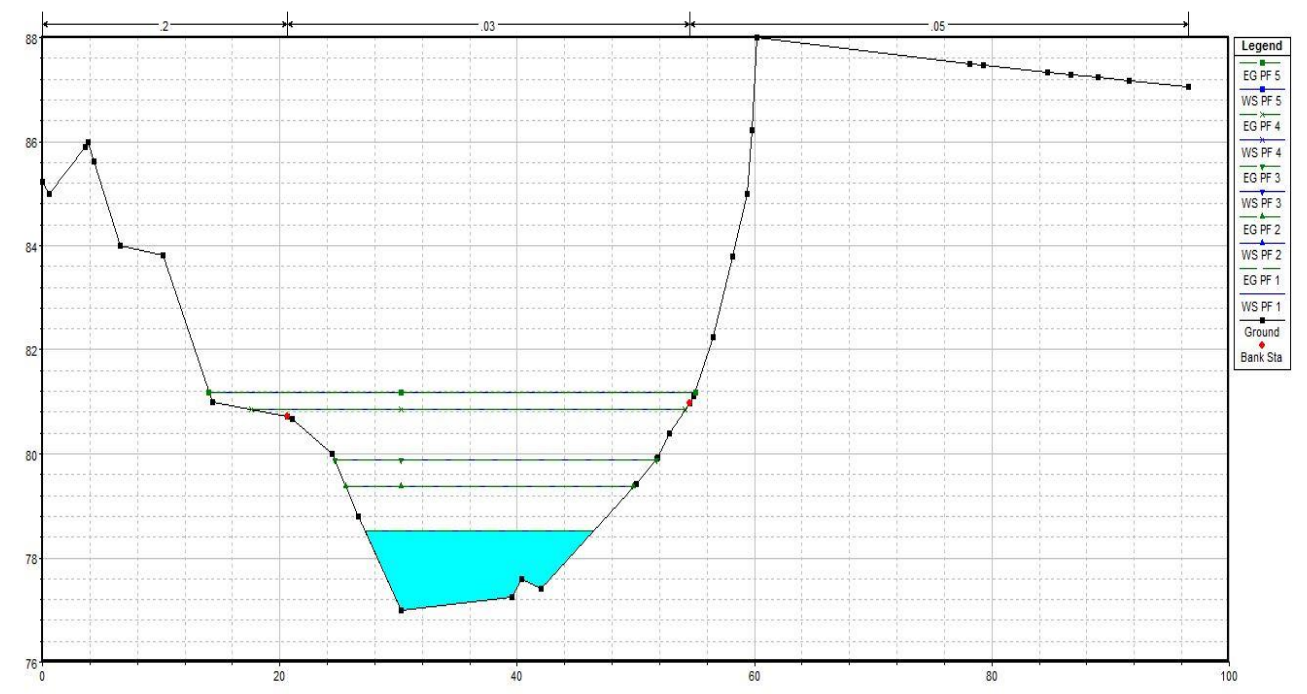
Figure 6 Cross section of the Vuka River near confluence, with specified water levels for different return periods

The range of velocities occurring on the analyzed cross section is $0.035-0.768 \mathrm{~m} / \mathrm{s}$. According to the distribution of velocities along the longitudinal profile shown in Figure 5, some values are higher, even up to $2 \mathrm{~m} / \mathrm{s}$ for the $100 \mathrm{yr}$ return period. Considering the fact that the Froude number is less than 1 , the flow for every analyzed return period is subcritical. The parameter that increases significantly is the size of the flow area because of the longer return period.

Table 3 Results of hydraulic simulation for cross section near confluence $(0+050 \mathrm{rkm})$

\begin{tabular}{ccccccccc}
$\begin{array}{c}\text { Return } \\
\text { period }\end{array}$ & $\begin{array}{c}\text { Discharge } \\
{\left[\mathrm{m}^{3} / \mathbf{s}\right]}\end{array}$ & $\begin{array}{c}\text { Bottom } \\
\text { elevation } \\
{[\text { [ma.s.I.] }}\end{array}$ & $\begin{array}{c}\text { Water } \\
\text { level } \\
{[\text { ma.s.l.] }}\end{array}$ & $\begin{array}{c}\text { En. line } \\
\text { elevation } \\
{[\text { [ma.s.l.] }}\end{array}$ & $\begin{array}{c}\text { Velocity } \\
{[\mathrm{m} / \mathbf{s}]}\end{array}$ & $\begin{array}{c}\text { Flow area } \\
{\left[\mathrm{m}^{2}\right]}\end{array}$ & $\begin{array}{c}\text { Top } \\
\text { width [m] }\end{array}$ & $\begin{array}{c}\text { Froude } \\
\text { number [-] }\end{array}$ \\
\hline 2 & 1.12 & 76.56 & 78.4 & 78.4 & 0.0351 & 31.89 & 23.61 & 0.0096 \\
5 & 4.94 & 76.56 & 79.36 & 79.36 & 0.0864 & 57.2 & 28.88 & 0.0196 \\
10 & 11.23 & 76.56 & 79.88 & 79.88 & 0.1542 & 72.82 & 31.11 & 0.0322 \\
25 & 27.88 & 76.56 & 80.46 & 80.46 & 0.3049 & 91.43 & 33.05 & 0.0585 \\
50 & 51.14 & 76.56 & 80.84 & 80.85 & 0.4906 & 104.23 & 34.32 & 0.0899 \\
100 & 89.3 & 76.56 & 81.19 & 81.22 & 0.7676 & 116.45 & 35.49 & 0.134
\end{tabular}

Three-dimensional models of the riverbed with water levels obtained in HEC-RAS are shown in Figure 7 for every analyzed return period. As the return period increases, so does the volume of water in the riverbed and in the inundation areas. 


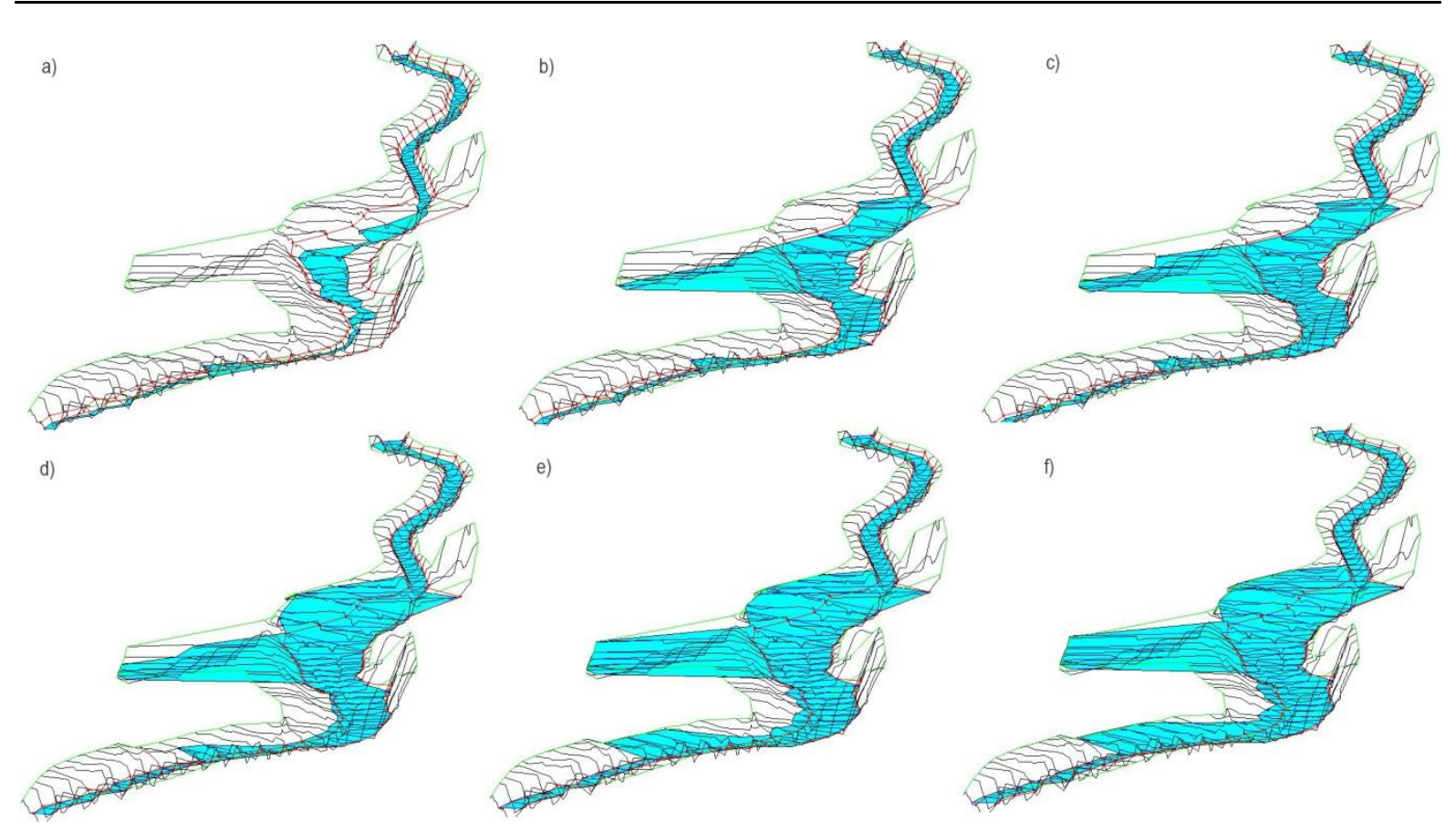

Figure 7 Three-dimensional models of riverbed with water levels for return periods of a) 2 yrs, b) 5 yrs, c) $10 \mathrm{yrs}$, d) $25 \mathrm{yrs}$, e) $50 \mathrm{yrs}$, f) $100 \mathrm{yrs}$

In order to analyze the flooded areas due to the occurrence of high water levels for different return periods, the hydraulic model of steady-state flow was imported into the ArcGIS software, where the size of the flooded area was calculated for every return period. Figure 8 shows the results obtained for two maximum return periods (50 and $100 \mathrm{yrs}$ ). The sizes of the flooded area for every return period are listed in Table 4. The range of area affected by flooding is $0.0563-0.3686 \mathrm{~km}^{2}$.

a)

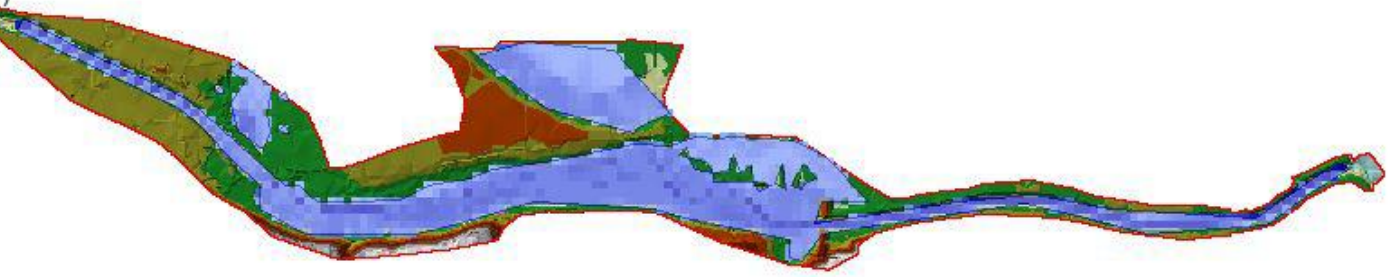

b)

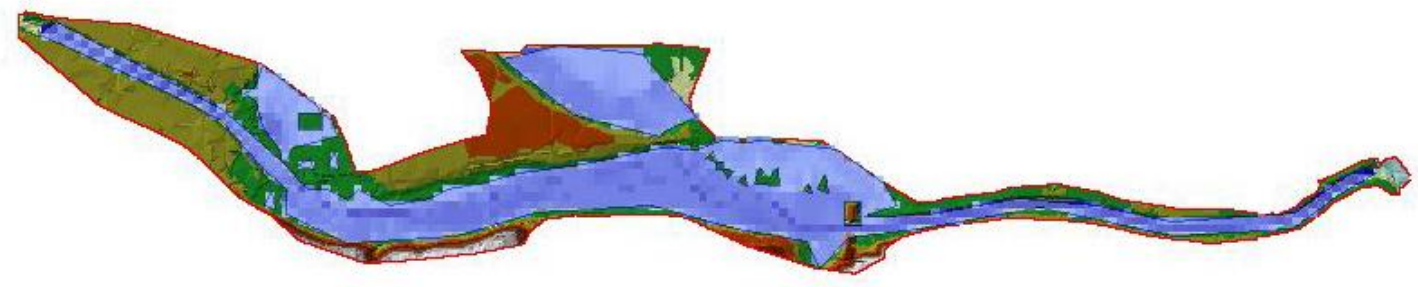

Figure 8 Flooded areas for return period a) $50 \mathrm{yrs}$, b) $100 \mathrm{yrs}$ 
Table 4 Flooded areas for return periods of $2,5,10,25,50$, and $100 \mathrm{yrs}$

\begin{tabular}{cc} 
Return period & Flooded area $\left[\mathbf{k m}^{2}\right]$ \\
\hline 2 & 0.0563 \\
5 & 0.1421 \\
10 & 0.2342 \\
25 & 0.2841 \\
50 & 0.3397 \\
100 & 0.3686
\end{tabular}

The analyzed flooded areas were assessed on flood hazard maps that are based on the probability of flood occurrence. The maps were made as part of the plan for flood risk management in accordance with Articles 111 and 112 of the Water Act, and can be found on the web pages of the Croatian Waters institution [15]. According to those maps, the area of the Vuka River near confluence is characterized as an area with medium (light blue) and high (dark blue) probability of flood occurrence (Figure 9). The sections of the Vuka River where the biggest floods occur according to the obtained hydraulic model results correspond with those map segments marked as areas with a high probability of flood occurrence.
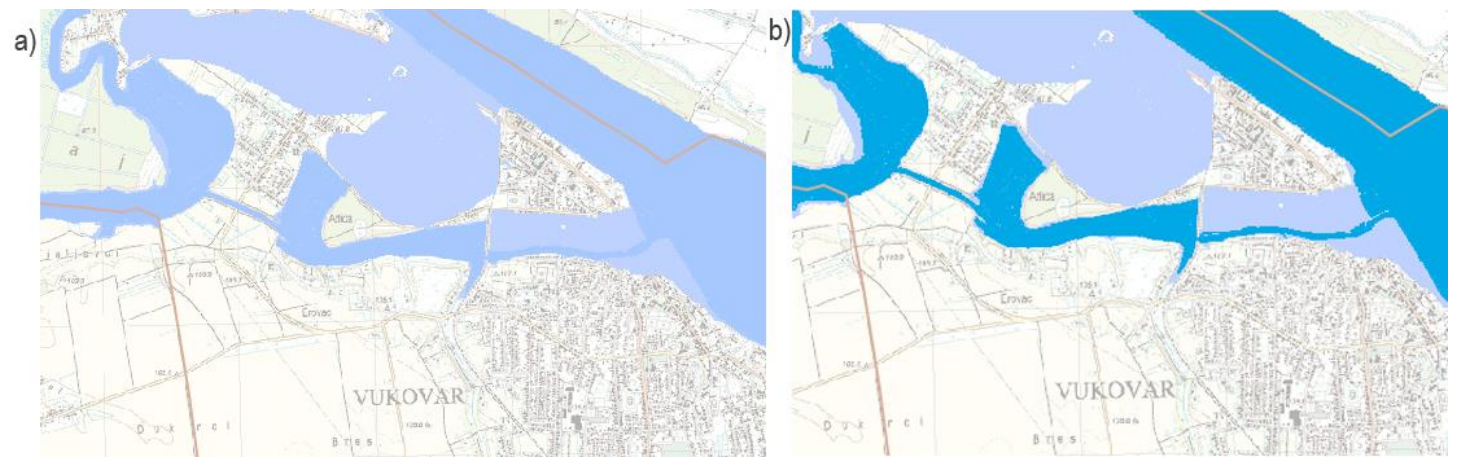

Figure 9 Flood hazard maps: a) medium-occurrence probability; b) high-occurrence probability [15]

\section{CONCLUSION}

The confluence of the Vuka River with the Danube River is situated in Vukovar. Throughout history, numerous large-scale floods have occurred in this area. The leading cause of flood episodes is high water levels in the Danube River, which cause backwater in the Vuka River. Hence, flooding in this area is due to an interaction between two watercourses. The area of Vukovar that is endangered by floods is not populated because it is a natural floodplain and part of the city's flood protection system.

Because of the frequent floods, a hydraulic model was constructed based on a digital model of the riverbed and the surrounding terrain. Discharges of the Vuka River and water levels of the Danube River were calculated for different return periods and were incorporated into the model. The results obtained were analyzed in the GIS software ArcGIS. Calulation of the size of the flooded areas showed a significant increase for higher return periods. The sections in which the biggest water flooding occurs are within segments without regulation works that are situated in a wide river valley. Because of water logging and loss of the riverbed form, large-scale floods occur on this section. The results obtained from this model and analysis are in accordance with flood hazard maps issued by the Croatian Waters institution that were created as a large-scale model. In the small-scale model obtained with this analysis, the sections where minor flooding occurs correspond to areas on the map with medium probability of 
flood occurrence. The areas on the map with a high probability of flood occurrence correspond to the sections in the model where large-scale flooding occurs.

Even though obtained results are in accordance with large-scale analysis, for comprehensive and more detailed hydraulic analysis longer time series, analysis of coincidence and model calibration are needed.

\section{References}

[1] Nadilo, B. 2012: Nova akumulacija na slivu rijeke Vuke, zaštita od poplava i navodnjavanje. Građevinar, 64 (10), pp. 833-844 (in Croatian)

[2] Živaković-Kerže, Z. 2008: Ivan Nepomuk Spannbauer i njegovo značenje za odvodnju osječkoga kraja (Poseban osvrt na isušivanje močvare Palača). VDG Jahrbuch, 15, pp. 117-126 (in Croatian)

[3] Institut IGH d.d., Zagreb. 2011: Studija vodnogospodarskog uređenja sliva rijeke Vuke (in Croatian)

[4] Đuroković, Z.; Biondić, D.; Sitar S. 2012: Poplave i obrana od poplava u Republici Hrvatskoj i uloga i značenje glavnog centra obrane od poplava, Okrugli stol: Zaštita od poplava u Hrvatskoj, Biondić and Holjević, pp. 9-22. (in Croatian)

[5] Geoportal, https://geoportal.dgu.hr/ Accessed 1 November 2016.

[6] US Army Corps of Engineers 2009: HEC-GeoRAS 4.2 UsersManual

[7] Corine Land Cover 2000 Hrvatska. http://corine.azo.hr/ Accessed 1 November 2016.

[8] Kušan, V. 2015: CORINE pokrov zemljišta Hrvatska, Hrvatska agencija za okoliš i prirodu (in Croatian)

[9] US Army Corps of Engineers 2010: HEC - RAS 4.1 Users Manual

[10] Singh, V.P. \& Arora K. 1989: A comparative evaluation of the estimators of the log Pearson type (LP) 3 distribution, Journal of Hydrology, 105, pp. 19-37.

[11] Singh, V.P. 1998: Entropy-Based Parameter Estimation in Hydrology, Ch. Log-Pearson Type III Distribution, Springer Nethe rlands, pp. 252-274, https://doi.org/10.1007/978-94-017-1431-0 15

[12] Stedinger, J. R.; Griffis, V. W. 2008: Flood Frequency Analysis in the United States: Time to Update, Journal of Hydrologic Engineering, pp. 199-204.

[13] Streamflow Evaluations for Watershed Restoration Planning and Design, http://water.oregonstate.edu. Accessed 1 November 2016.

[14] Tadić, L.; Dadić T.; Barač, B. 2013: Flood Frequency Modelling Of Kopački Rit Nature Park, Tehnički vjesnikTechnical Gazette, 20 (1), pp. 51-57

[15] Karte opasnosti od poplava i karte rizika od poplava, http://voda.giscloud.com/map/321490/karta-opasnosti-odpoplava-po-vjerojatnosti-poplavlijivanja (in Croatian) Accessed 1 November 2016. 